\title{
Titus Phase Ceramic Vessel and Elbow Pipe from the Gus Bogan Farm Site (41WD25), Wood County, Texas
}

Timothy K. Perttula

Heritage Research Center, Stephen F. Austin State University

Follow this and additional works at: https://scholarworks.sfasu.edu/ita

Part of the American Material Culture Commons, Archaeological Anthropology Commons, Environmental Studies Commons, Other American Studies Commons, Other Arts and Humanities Commons, Other History of Art, Architecture, and Archaeology Commons, and the United States History Commons

Tell us how this article helped you.

This Article is brought to you for free and open access by the Center for Regional Heritage Research at SFA ScholarWorks. It has been accepted for inclusion in Index of Texas Archaeology: Open Access Gray Literature from the Lone Star State by an authorized editor of SFA ScholarWorks. For more information, please contact cdsscholarworks@sfasu.edu. 


\section{Titus Phase Ceramic Vessel and Elbow Pipe from the Gus Bogan Farm Site (41WD25), Wood County, Texas}

\section{Creative Commons License}

\section{(c) (1) (8)}

This work is licensed under a Creative Commons Attribution-NonCommercial 4.0 International License 


\title{
Titus Phase Ceramic Vessel and Elbow Pipe from the Gus Bogan Farm Site (41WD25), Wood County, Texas
}

\author{
Timothy K. Perttula
}

\section{Introduction}

The Gus Bogan Farm site, located 1 mile north of the city of Mineola, Texas, in the upper Sabine River basin (Figure 1), was recorded by University of Texas at Austin (UT) archaeologists in 1935 based on the photographic documentation of ancestral Caddo ceramic vessels and elbow pipe in the Gus T. Bogan, Sr. and Gus T. Bogan, Jr. collections from the site. The Bogan's were digging a Caddo cemetery there, and loaned a portion of their recovered collections to the University Centennial Exposition for the duration of the exhibit. Analyses of the vessels and pipe in this article are based on the examination of Xerox copies of the photographs in the Texas Archeological Research Laboratory site files. Information on temper, surface treatment, firing conditions, etc., of the vessels and pipe was not obtained during the 1935 photographic documentation, however, or any description of decorative methods, motifs, or elements.

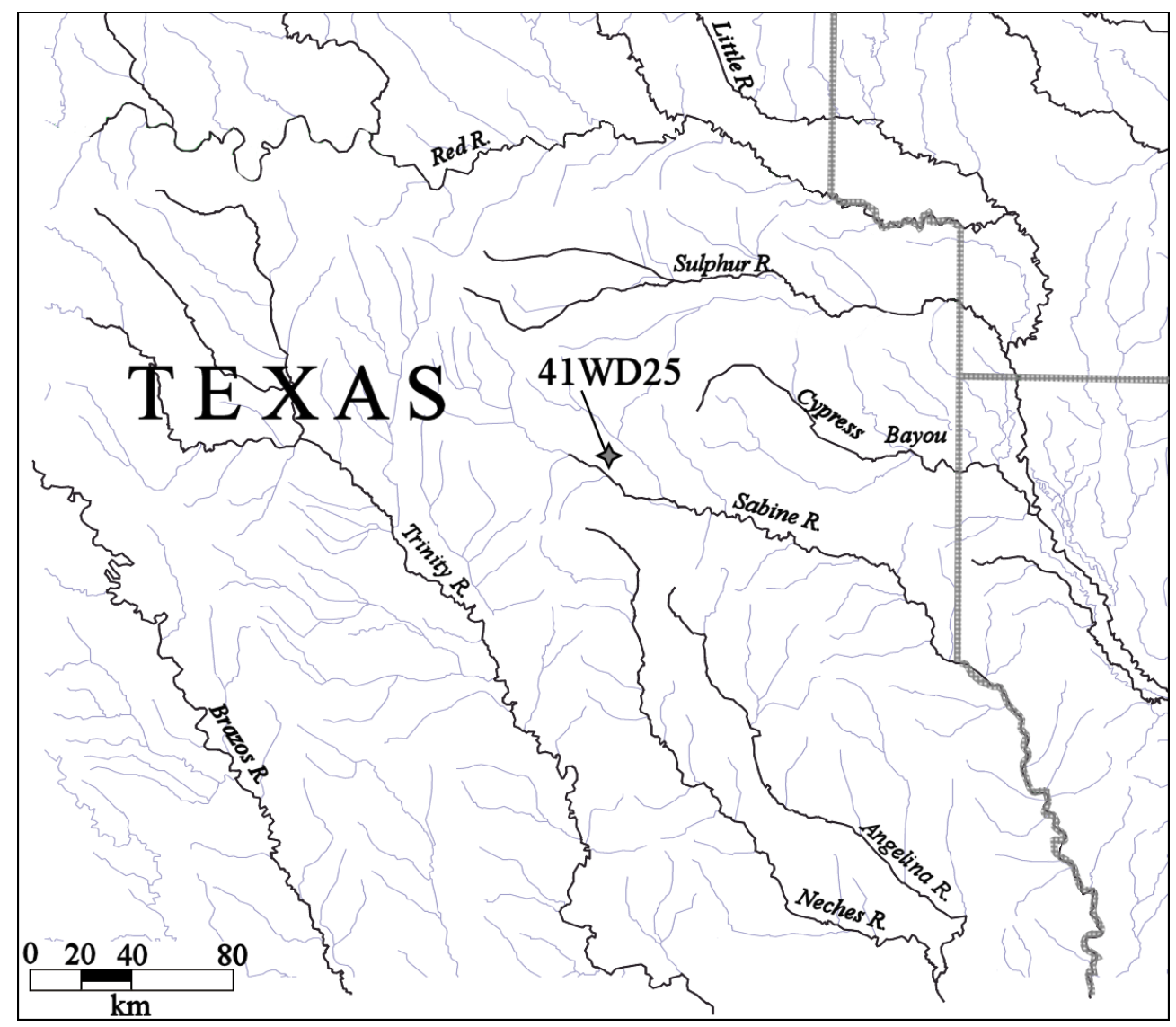

Figure 1. General location of the Gus Bogan Farm site (41WD25) in East Texas. 


\section{Ceramic Vessels}

Six ceramic vessels from the Gus Bogan Farm site were photo-documented by UT archaeologists in 1935. They include both utility ware and fine ware vessels.

The one utility war is a medium-sized Cass Appliqued jar with a series of vertical appliqued ridges on the vessel body (Figure 2; see also Suhm and Jelks 1962:Plate 13). Such vessels occur in post-A.D. 1550 contexts in Titus phase sites as well as contemporaneous sites in the Sulphur River and Big Cypress Creek basins (Perttula 2020).

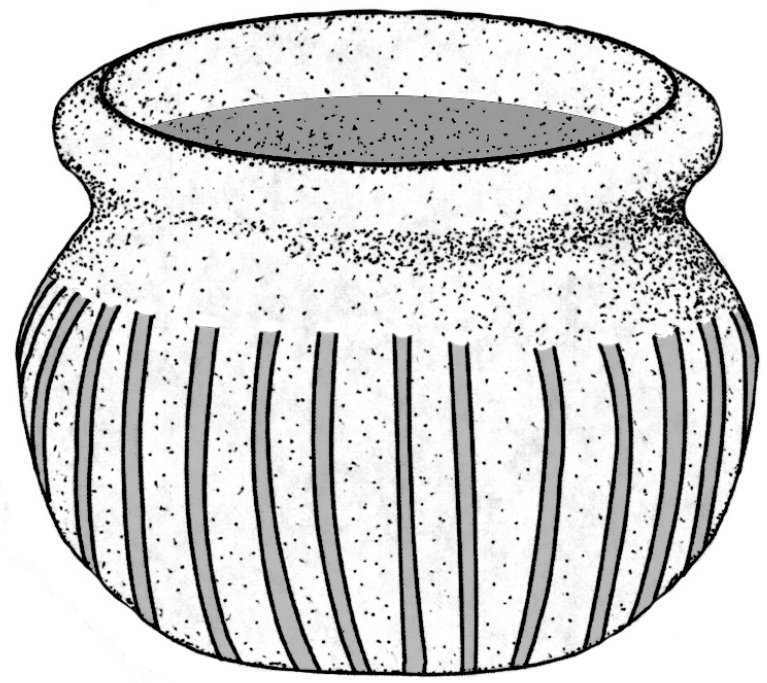

Figure 2. Cass Appliqued jar from the Gus Bogan Farm site.

The fine ware vessels include one bowl (Figure 3), three carinated bowls (Figures 4-6), and a large bottle (Figure 7). The bowl is a Taylor Engraved vessel with sets of concentric circles and hooked arm elements. The carinated bowls include a Ripley Engraved, var. Gandy vessel with an inverted rim (Figure 4; see Fields 2020), a Simms Engraved inverted rim vessel with a series of large open pendant triangles on the rim panel (Figure 5), and a Taylor Engraved vessel with sets of curvilinear engraved lines and hooked arm elements in a mid-rim panel (Figure 6).

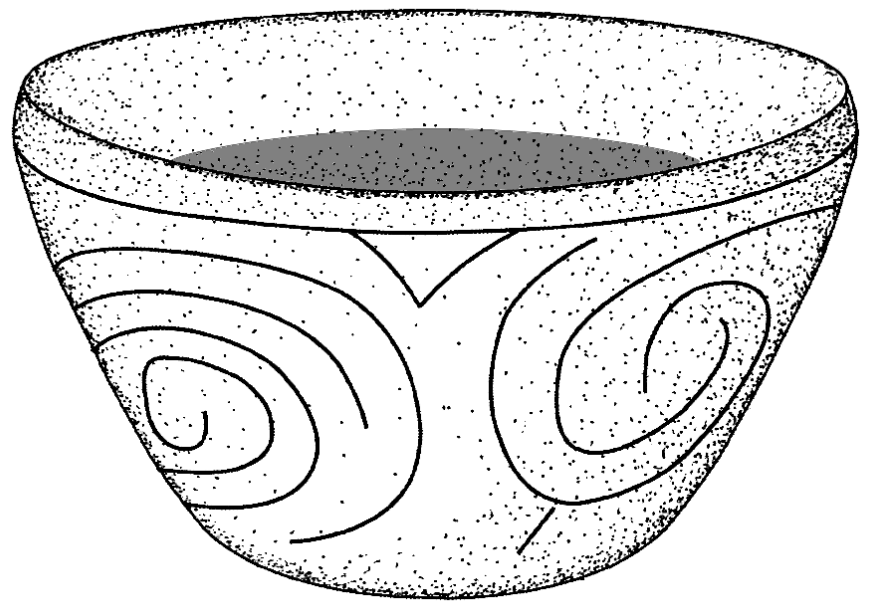

Figure 3. Taylor Engraved bowl from the Gus Bogan Farm site. 


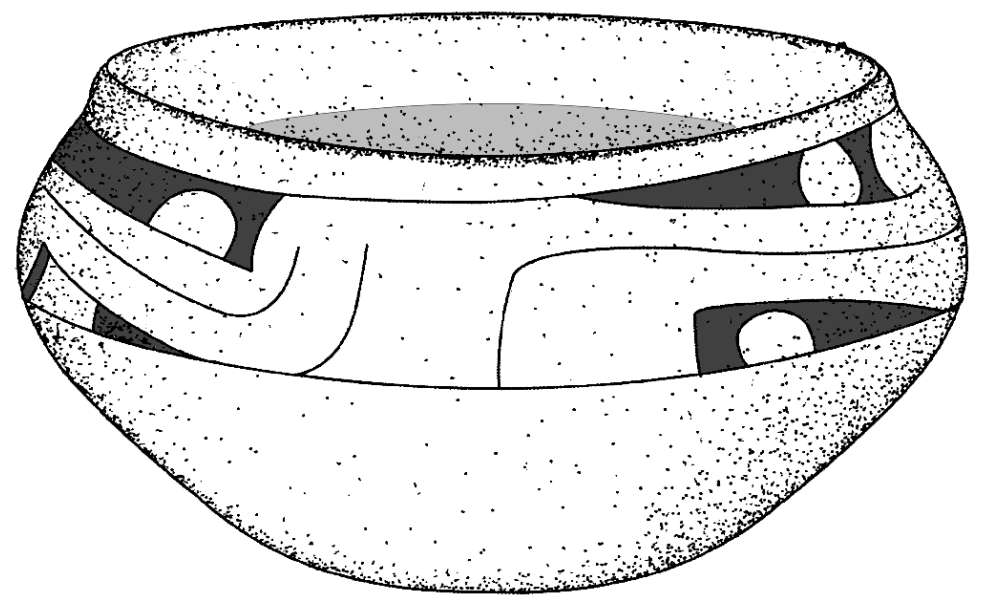

Figure 4. Ripley Engraved, var. Gandy carinated bowl from the Gus Bogan Farm site.

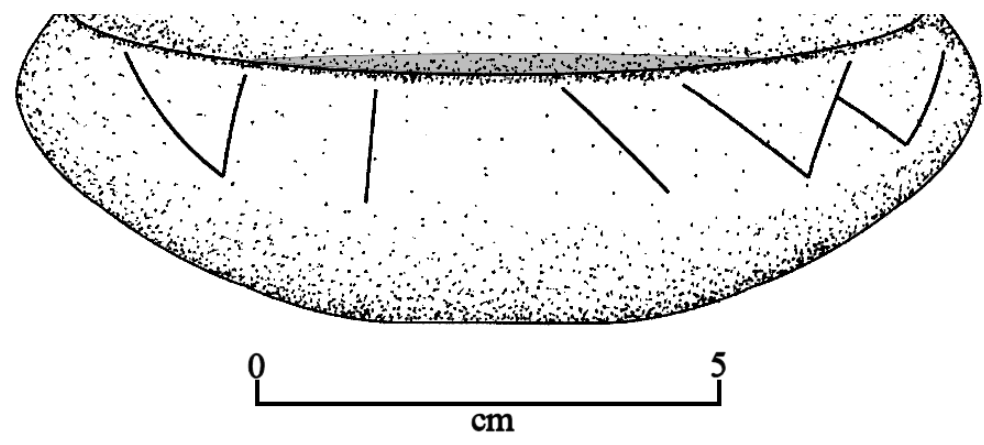

Figure 5. Simms Engraved carinated bowl from the Gus Bogan Farm site.

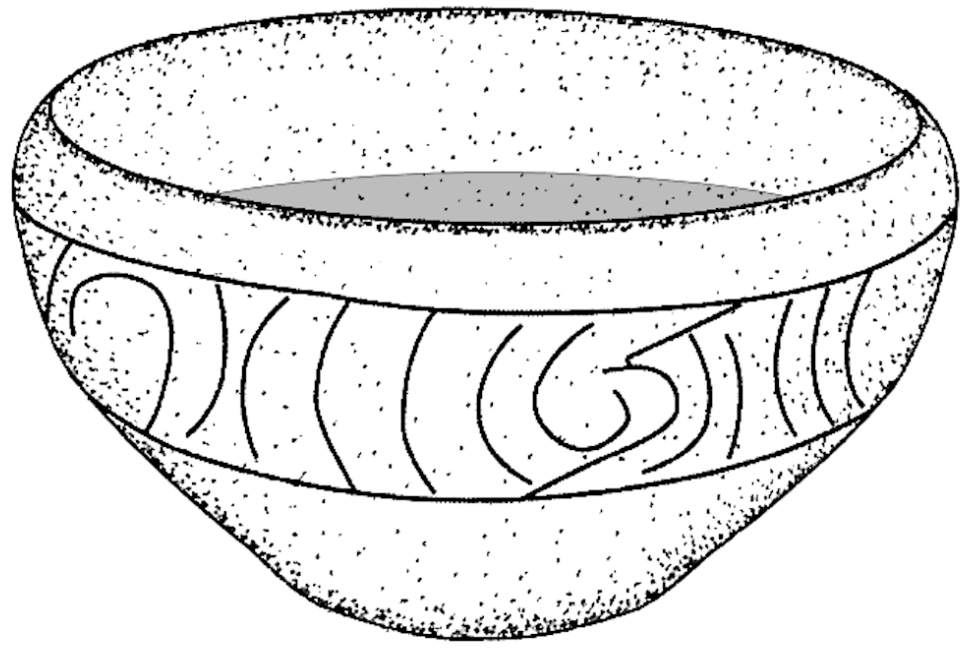

Figure 6. Taylor Engraved carinated bowl from the Gus Bogan Farm site. 


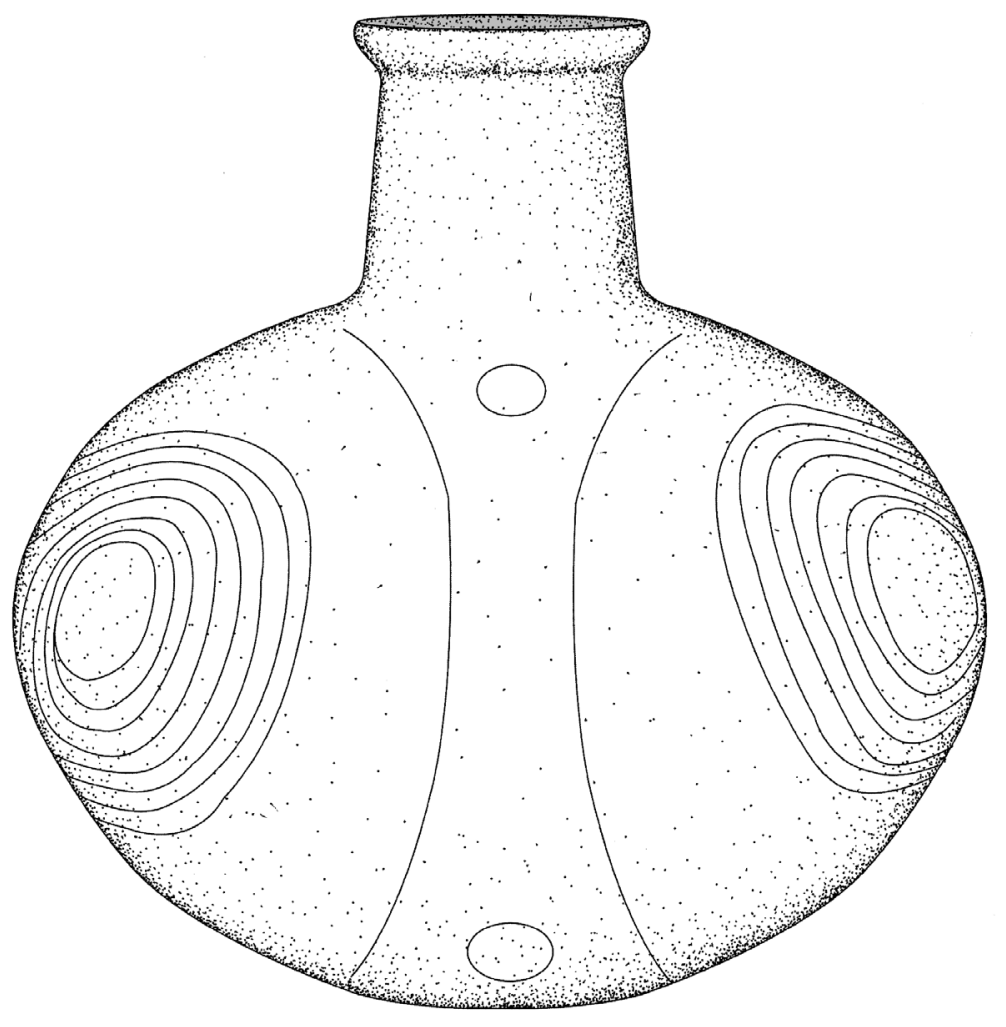

Figure 7. Taylor Engraved bottle from the Gus Bogan Farm site.

The one bottle in the ancestral Caddo vessel collection from the Gus Bogan Farm site is a Taylor Engraved bottle (see Figure 7; see Suhm and Jelks 1962:Plate 76). The vessel body is divided into panels by large engraved brackets with upper and lower circle elements. The panels themselves each have one large set of engraved concentric circles.

\section{Ceramic Pipe}

The elbow pipe from the Gus Bogan site has a large bowl and a short stem, and has engraved decorative elements on both the bowl and staem (Figure 8). The bowl has a series of large pendant triangles filled with cross-hatched engraved lines, while there are two horizontal engraved lines

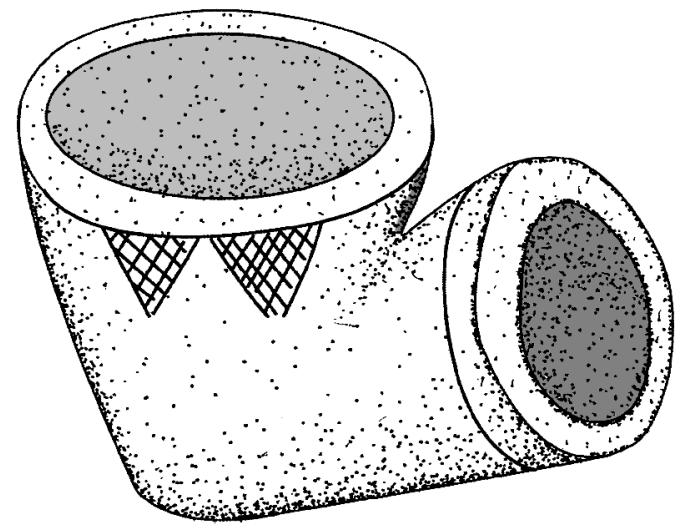

Figure 8. Engraved elbow pipe from the Gus Bogan Farm site. 
below the lip on the stem. Similar styles of engraved elbow pipes have been recovered from the Caney Creek locality in the upper Sabine River basin (Perttula et al. 2009:209).

\section{Summary and Conclusions}

The stylistic character of the ancestral Caddo ceramic vessels and engraved elbow pipe from the Gus Bogan Farm site suggests that there are burial features there that are part of a number of known late (ca. A.D. 1550-1680) Titus phase sites that are part of a community of Caddo peoples that lived in the Post Oak Savannah in the $16^{\text {th }}$ century as well as much of the $17^{\text {th }}$ century. Western tradition late Titus phase sites occur in the middle and upper parts of the Big Cypress Creek basin, as well as in the upper Sabine and White Oak Creek basins (Perttula 2009, 2016:Figure 35), in particular the Stouts Creek locality in the White Oak Creek basin, and the Caney Creek and Dry Creek localities in the Lake Fork Creek drainage of the upper Sabine River basin (Perttula et al. 2009:96-194; Walters 2007). Burial features at these sites tend to have Hudson Engraved, Ripley Engraved, Simms Engraved, Taylor Engraved, Wilder Engraved, and Womack Engraved as well as utility ware types Cass Appliqued, La Rue Neck Banded, Mockingbird Punctated, Moore Noded, and McKinney Plain and plain ware vessels. Fine ware vessels tend to have inverted rims on carinated bowls and spoolnecked bottles are also present in these late Titus phase vessel assemblages.

\section{Acknowledgments}

Lance K. Trask prepared the figures in this article. Thanks to the staff at the Texas Archeological Research Laboratory at The University of Texas at Austin for access to the site files and records.

\section{References Cited}

Fields, R. C.

2020 Communities of Ceramic Practice within the Titus Phase. In Ancestral Caddo Ceramic Traditions, edited by D. P. McKinnon, J. S. Girard, and T. K. Perttula. Louisiana State University Press, Baton Rouge, in press.

Perttula, T. K.

2009 The Archaeology of the $16^{\text {th }}$ and $17^{\text {th }}$ Century Caddo in the Post Oak Savannah of Northeast Texas: The Tuinier Farm (41HP237), R. A. Watkins (41HP238), and Anglin (41HP240) Sites in the Stouts Creek Basin, Hopkins County, Texas. Journal of Northeast Texas Archaeology 30:1-132.

2016 Documentation of the Caddo Ceramic Vessels from the Culpepper Site (41HP1) in Hopkins County in the Upper Sulphur River Basin in East Texas. Journal of Northeast Texas Archaeology 65:53-98.

2020 East Texas Caddo Ceramic Traditions. In Ancestral Caddo Ceramic Traditions, edited by D. P. McKinnon, J. S. Girard, and T. K. Perttula. Louisiana State University Press, Baton Rouge, in press.

Perttula, T. K., M. Walters, S. Marceaux, and B. Nelson

2009 Caddo Pottery Vessels and Pipes from Sites in the Middle and Upper Sabine and Upper Neches River Basins, Smith and Wood Counties, Texas. Special Publication No. 7. Friends of Northeast Texas Archaeology, Pittsburg and Austin. 
Suhm, D. A. and E. B. Jelks (editors)

1962 Handbook of Texas Archeology: Type Descriptions. Special Publication No. 1, Texas Archeological Society, and Bulletin No. 4, Texas Memorial Museum, Austin.

Walters, $\mathrm{M}$.

2007 Late Titus Phase Sites along Caney Creek in Northern Wood County, Texas. Journal of Northeast Texas Archaeology 26:145-149. 